medRxiv preprint doi: https://doi.org/10.1101/2021.05.31.21258061; this version posted June 3, 2021. The copyright holder for this preprint (which was not certified by peer review) is the author/funder, who has granted medRxiv a license to display the preprint in perpetuity. It is made available under a CC-BY-NC-ND 4.0 International license .

\title{
Association between motor task acquisition and hippocampal atrophy across cognitively unimpaired, amnestic Mild Cognitive Impairment, and Alzheimer's disease individuals
}

Sydney Y. Schaefer ${ }^{\mathrm{a}}$, Michael Malek-Ahmadi ${ }^{\mathrm{b}}$, Andrew Hooyman ${ }^{\mathrm{a}}$, Jace B. King ${ }^{\mathrm{c}}$, Kevin Duff ${ }^{\mathrm{d}}$

${ }^{a}$ School of Biological and Health Systems Engineering, Arizona State University, 501 E. Tyler Mall, MC 9709, Tempe, AZ 85287, USA; 'banner Alzheimer's Institute, 901 E. Willetta St., Phoenix, AZ 85006, USA; 'Department of Radiology and Imaging Sciences, University of Utah, 30 North 1900 East \#1A071, Salt Lake City, UT 84132-2140, USA; 'Center for Alzheimer's

Care, Imaging, \& Research, University of Utah, 650 Komas Dr. 106A,

Salt Lake City, UT 84108-1225, USA

Corresponding author: Sydney Schaefer, $\mathrm{PhD}$

501 E. Tyler Mall, MC 9709

Tempe, AZ 85287

480-727-6651

sydney.schaefer@asu.edu

\begin{abstract}
Hippocampal atrophy is a widely used biomarker for Alzheimer's disease (AD), but the cost, time, and contraindications associated with magnetic resonance imaging (MRI) limit its use. Recent work has shown that a low-cost upper extremity motor task has potential in identifying AD risk. Fifty-four older adults (15 cognitively unimpaired, 24 amnestic Mild Cognitive Impairment, and $15 \mathrm{AD}$ ) completed six motor task trials and a structural MRI. Motor task acquisition significantly predicted bilateral hippocampal volume, controlling for age, sex, education, and memory. Thus, this motor task may be an affordable, non-invasive screen for AD risk and progression.
\end{abstract}

Key words: psychomotor performance; Hippocampus; Mild Cognitive Impairment; Alzheimer Disease 
medRxiv preprint doi: https://doi.org/10.1101/2021.05.31.21258061; this version posted June 3, 2021. The copyright holder for this preprint (which was not certified by peer review) is the author/funder, who has granted medRxiv a license to display the preprint in perpetuity. It is made available under a CC-BY-NC-ND 4.0 International license .

\section{INTRODUCTION}

Hippocampal atrophy is a widely used biomarker for Alzheimer's disease (AD) stage and progression [1-3]. It is measured using magnetic resonance imaging (MRI), which is cheaper, more widely available, or less invasive than other biomarker testing, such as positron emission tomography and lumbar puncture. However, it still requires extensive equipment, staff, and time, and has a number of contraindications that limit its use among older adults specifically [4]. Factors like claustrophobia or high body mass further restrict MRI use for geriatrics. Older adults are also more likely to move more while in the scanner, affecting scan quality [5]. Furthermore, the need for medical personnel and settings (i.e., hospital) disproportionately discourages underrepresented minorities from participating in clinical trials and biomedical research $[6,7]$ and seeking diagnoses or treatment [8]. Thus, a low-cost, non-invasive, and widely-accessible method to identify hippocampal atrophy in older adults is needed.

Motor behavior may be a potential biomarker that addresses these needs, as complex upper-limb movements have been associated with AD severity [9-11]. Recent work has demonstrated that a rapid, easy-to-administer upper-limb motor task involving adaptive fine motor skill can predict disease progression [12] and is more sensitive to cognitive status than other simple motor assessments [13] while requiring no computer hardware/software. It is feasible for amnestic Mild Cognitive Impairment (aMCI) cohorts to perform [12, 14], and with repeated exposure it can show within-session practice effects (i.e., motor task acquisition) that indicate intact learning ability [14-16] (consistent with [17]). This is in contrast to other motor tasks that require technology (e.g., movement sensors [11], motion capture [10], electromyography [9], or transcranial magnetic stimulation [18]) and often show a ceiling effect. Given the task's association with disease progression and cognitive status, this short report tested 
medRxiv preprint doi: https://doi.org/10.1101/2021.05.31.21258061; this version posted June 3, 2021. The copyright holder for this preprint (which was not certified by peer review) is the author/funder, who has granted medRxiv a license to display the preprint in perpetuity.

It is made available under a CC-BY-NC-ND 4.0 International license .

its relationship with hippocampal volume across the AD spectrum (i.e., cognitively unimpaired, aMCI, and mild AD). We hypothesized that motor task acquisition would be related to hippocampal volume, even after controlling for age, sex, education, and memory function.

\section{METHODS}

\section{Participants}

Fifty-four older adults participated in this study, who were a subset of ClinicalTrials.gov NCT03466736 recruited through April 2019. Fifteen were cognitively unimpaired (CU) $($ mean \pm SD age $=71.9 \pm 4.8$ years; 13 females; $17.1 \pm 1.8$ years of education $), 24$ were classified with amnestic MCI (aMCI) (mean \pm SD age $=74.1 \pm 5.7$ years; 16 females; $15.1 \pm 2.7$ years of education), and 15 were classified with $\mathrm{AD}$ (mean $\pm \mathrm{SD}$ age $=78.6 \pm 6.1$ years; 7 females; 16.4 \pm 2.26 years of education). All participants were White non-Hispanic. Although most aMCI and $\mathrm{AD}$ participants were recruited from a cognitive disorders clinic, clinical status was confirmed with the Alzheimer's Disease Neuroimaging Initiative [19] classification battery, which included the Mini Mental Status Examination [20], Clinical Dementia Rating Scale [21], and the Wechsler Memory Scale-Revised [22] Logical Memory II Paragraph A.

Participants were included if they were $\geq 65$ years of age and had a knowledgeable collateral source available to comment on their cognition and daily functioning. Participants were excluded for medical comorbidities likely to affect cognition (including neurological conditions, current severe depression, substance abuse, and major psychiatric conditions); the inability to complete MRI; the inability to complete cognitive and motor assessments due to inadequate vision, hearing, or manual dexterity; and enrollment in any clinical drug trial related to anti-amyloid agents. Additional exclusion criteria included elevated depression (15-item 
medRxiv preprint doi: https://doi.org/10.1101/2021.05.31.21258061; this version posted June 3, 2021. The copyright holder for this preprint (which was not certified by peer review) is the author/funder, who has granted medRxiv a license to display the preprint in perpetuity.

It is made available under a CC-BY-NC-ND 4.0 International license .

Geriatric Depression Scale score >5), and moderate or severe dementia (Clinical Dementia Rating score $\geq 2$ or a Mini Mental Status Examination score $<20$ ). This study was approved by the University of Utah Institutional Review Board. All participants provided informed consent as self or by proxy prior to enrollment in accord with the Helsinki Declaration of 1975.

Participants underwent extensive neuropsychological assessment; however, only the Delayed Memory Index from the Repeatable Battery for the Assessment of Neuropsychological Status (RBANS, [23]) was examined here for memory function. All subtests were administered and scored as defined in the manual, and normative data from the RBANS manual were used to calculate this Index score as an age-corrected standard score $(\mathrm{M}=100, \mathrm{SD}=15)$ with higher scores indicating better cognition. Mean \pm SD RBANS Delayed Memory Index scores were 110.5 $\pm 9.9,70.1 \pm 18.0$, and 50.1 \pm 9.9 for the CU, aMCI, and AD groups, respectively, consistent with their clinical status.

\section{Timed motor task}

Visual demonstration of the motor task can be viewed on Open Science Framework (https://osf.io/phs57/wiki/Functional_reaching_task/), and its methods have been published previously $[12,14,24,25]$. This task has also been validated against clinical activities of daily living measures [12] in aMCI patients. To summarize, participants use a standard plastic spoon to acquire two raw kidney beans at a time from a central cup (all cups $9.5 \mathrm{~cm}$ diameter and $5.8 \mathrm{~cm}$ deep) to one of three distal cups arranged at a radius of $16 \mathrm{~cm}$ at $-40^{\circ}, 0^{\circ}$, and $40^{\circ}$ relative to the central cup. Participants used their nondominant hand (to avoid ceiling effects), and started by moving to the cup ipsilateral (same side) of the hand used. They then returned to the central cup to acquire two more beans at a time to transport to the middle cup, then the contralateral cup, and 
medRxiv preprint doi: https://doi.org/10.1101/2021.05.31.21258061; this version posted June 3, 2021. The copyright holder for this preprint (which was not certified by peer review) is the author/funder, who has granted medRxiv a license to display the preprint in perpetuity. It is made available under a CC-BY-NC-ND 4.0 International license .

then repeated this sequence four more times for a total of 15 out-and-back movements. Task performance was recorded as trial time (in seconds, via stopwatch); lower values indicate better performance. Movement errors, such as dropping beans mid-reach, were recorded; however, only $1 \%$ of all reaches had any errors, and the error rate was similar across groups $(\mathrm{p}=.70)$. Participants completed 6 trials of the task. This amount of practice was based on a) previous work demonstrating that cognitively intact older adults typically reach stable performance after 5 trials $[16,26]$, and b) clinical pragmatism to minimize participant burden $(\sim 5$ minutes to administer). Task acquisition was measured as the amount of variability (inter-subject standard deviation) in performance across the practice trials, such that higher standard deviations indicated less task acquisition. Figure 1 illustrates different degrees of acquisition for an individual CU, aMCI, and AD participant, such that the CU participant had better acquisition (less variability) and the AD participant has worse acquisition (more variability) across trials. This illustrates the value of administering more than one trial of the task, allowing for any practice effect. Additional measures of performance included overall mean (averaged across the six trials) and acquisition 'slope' (Trial 6 - Trial 1). The measure of acquisition slope is similar to the California Verbal Learning Test learning slope [27], which can differentiate between demented and nondemented older adults [28].

\section{MR Imaging Procedure}

Acquisition of imaging data was performed at the Utah Center for Advanced Imaging Research (UCAIR) using a 3.0-T Siemens Prisma scanner with a 64-channel head coil. Structural data was acquired using an MP2RAGE pulse sequence $(\mathrm{TR}=5000, \mathrm{TE}=2.93$, acquired sagittally, resolution=1 x $1 \times 1 \mathrm{~mm}$ ) to obtain high quality whole-brain $1 \mathrm{~mm}$ isotropic $\mathrm{T} 1 \mathrm{w}$ images with 
medRxiv preprint doi: https://doi.org/10.1101/2021.05.31.21258061; this version posted June 3, 2021. The copyright holder for this preprint (which was not certified by peer review) is the author/funder, who has granted medRxiv a license to display the preprint in perpetuity. It is made available under a CC-BY-NC-ND 4.0 International license .

improved signal homogeneity in $\sim 7$ minutes. Structural MRI scans were processed using FreeSurfer image analysis suite v6.0 (http://surfer.nmr.mgh.harvard.edu/). Technical details are described previously [29-31]. Left and right hippocampal volumes were adjusted by estimated total intracranial volume (eTIV, $\mathrm{cm}^{3}$ ) to account for differences in head size, and then summed to yield bilateral hippocampal volumes.

\section{Statistical analysis}

All analyses were performed in R (v3.5.1). Both hippocampal volume and mean task performance were first compared between groups using a one-way ANOVA to determine differences between clinical status. Multivariate linear regression was then conducted to predict bilateral hippocampal volume using participants' motor task acquisition (i.e., standard deviation) as a predictor while controlling for age, sex, years of education, clinical status, and RBANS Delayed Memory Index score; these factors were included given their known associations with hippocampal volume. The normality assumption for bilateral hippocampal volume was tested using the Shapiro-Wilk test. The motor task variables of acquisition, overall mean, and acquisition slope were separately added to the null regression model (age, sex, years of education, clinical status, and RBANS Delayed Memory Index score) to determine if the contribution of the motor task provided additional predictive value beyond the RBANS Delayed Memory Index score. Akaike's Information Criteria (AIC) and adjusted $\mathrm{R}^{2}$ values from each model were compared.

\section{RESULTS}


medRxiv preprint doi: https://doi.org/10.1101/2021.05.31.21258061; this version posted June 3, 2021. The copyright holder for this preprint (which was not certified by peer review) is the author/funder, who has granted medRxiv a license to display the preprint in perpetuity.

It is made available under a CC-BY-NC-ND 4.0 International license .

One-way ANOVA confirmed a significant effect of clinical status on bilateral hippocampal volumes $\left(\mathrm{F}_{2,53}=15.6 ; \mathrm{p}<.0001\right)\left(\mathrm{CU}=4.55 \pm 0.79 \mathrm{~cm}^{3}, 95 \% \mathrm{CI}[4.11,4.98] ; \mathrm{aMCI}=3.56 \pm 0.55\right.$ $\left.\mathrm{cm}^{3}, 95 \% \mathrm{CI}[3.33,3.80] ; \mathrm{AD}=3.16 \pm 0.89 \mathrm{~cm}^{3}, 95 \% \mathrm{CI}[2.67,3.65]\right)$, consistent with their diagnosis. Furthermore, data showed that this motor task was feasible even for participants with mild $\mathrm{AD}$, even though there was main effect of group on mean task performance $\left(\mathrm{F}_{2,53}=5.52\right.$; $\mathrm{p}=.007$ ) with the AD group as the slowest. Mean task performance was not significantly related to hippocampal volume $(\mathrm{p}=.14)$, after controlling for age, sex, education, clinical status, and memory score. As shown in the individual participant data in Figure 1, the AD participant was not only slower but also had greater variability across trials (i.e., less task acquisition). Across participants, this variability across trials was sensitive to hippocampal volume, given that regression analyses revealed that motor task acquisition (measured as standard deviation of performance across the 6 practice trials) was a significant predictor of bilateral hippocampal volume $(\beta=-.03 ; 95 \%$ CI [-.07, -.0009]; $p=.04)$, even when controlling for age $(p=.46)$, sex $(p=.50)$, education $(p=.33)$, clinical status $(p=0.25)$, and memory score $(\beta=.01 ; 95 \%$ CI $[-.003$, $.02] ; \mathrm{p}=.11)$. The full model yielded an adjusted $\mathrm{R}^{2}=.36\left(\mathrm{~F}_{4,47}=6.1 ; \mathrm{p}<.0001\right)$. Comparison of the linear regression models demonstrated that adding either the motor acquisition or mean motor task performance variable to the null model yielded incremental improvements in predicting hippocampal volume, while adding acquisition slope increased the percent variance explained in hippocampal volume by 9\% compared to the RBANS Delayed Memory Index (Table 1).

\section{DISCUSSION}

This study tested the relationship between bilateral hippocampal volume and acquisition of a motor task in cognitively unimpaired, aMCI, and mild AD older adults. Results showed that even 
medRxiv preprint doi: https://doi.org/10.1101/2021.05.31.21258061; this version posted June 3, 2021. The copyright holder for this preprint (which was not certified by peer review) is the author/funder, who has granted medRxiv a license to display the preprint in perpetuity. It is made available under a CC-BY-NC-ND 4.0 International license .

after controlling for age, gender, education, clinical status, and memory, motor task acquisition was still a significant predictor of hippocampal volume, with worse task acquisition (i.e. more variable performance) being associated with lower hippocampal volume. This suggests that motor practice effects may better indicate hippocampal atrophy even after controlling for other clinical factors, which is particularly relevant for cases of MRI contraindication.

Although several complex upper-limb tasks have been shown to be sensitive to disease severity $[9,11]$, this is among the first to associate motor behavior with an AD biomarker. This work highlights the value of evaluating multiple trials of a motor task, rather than a "one-anddone" approach in which a single attempt could mask relevant differences. This is consistent with extensive work showing the clinical utility of cognitive practice effects [32-36]. Furthermore, these findings are consistent with behavioral data linking practice effects on this motor task with visuospatial scores $[16,37,38]$, suggesting a potential mechanism underlying the relationship to hippocampal volume shown here. Future research is needed, however, to examine whether declines in motor acquisition track with hippocampal atrophy (or other biomarkers) over time.

We acknowledge the high education levels and lack of racial/ethnic diversity within the relatively small sample. These limitations warrant future research in larger and diverse cohorts to better estimate the potential of this task as an affordable enrichment strategy for AD clinical trials. We also acknowledge that this study does not directly compare this motor task to other existing motor tasks (e.g., grip dynamometry, 10-Meter Walk Test), although we have previously shown that the motor task presented here is more sensitive to disease severity [24].

In addition to the growing evidence for this motor task as a relevant measure for $\mathrm{AD}$, it should be highlighted that only $\sim 5$ minutes are needed to administer several trials, and the 
apparatus costs $<\$ 10$ to fabricate from household items, thereby potentially improving detection of hippocampal atrophy with virtually no additional time or cost. It is also extremely portable, making it easy to administer outside of a clinical setting (e.g., at a community center or at home). Eliminating the need for medical staff/settings has the potential to better serve under-represented minorities. Future studies will test the reliability of administering this motor task in various settings across a more diverse sample.

\section{FUNDING}

This work was supported by the National Institutes of Health [grant numbers R01 AG055428 and K01AG047926]. The sponsors had no role in the design and conduct of the study; in the collection, analysis, and interpretation of data; in the preparation of the manuscript; or in the review or approval of the manuscript. 
medRxiv preprint doi: https://doi.org/10.1101/2021.05.31.21258061; this version posted June 3, 2021. The copyright holder for this preprint (which was not certified by peer review) is the author/funder, who has granted medRxiv a license to display the preprint in perpetuity. It is made available under a CC-BY-NC-ND 4.0 International license .

\section{REFERENCES}

[1] Kaye JA, Swihart T, Howieson D, Dame A, Moore MM, Karnos T, Camicioli R, Ball M, Oken B, Sexton G (1997) Volume loss of the hippocampus and temporal lobe in healthy elderly persons destined to develop dementia. Neurology 48, 1297-1304.

[2] Kantarci K, Jack CR, Jr. (2003) Neuroimaging in Alzheimer disease: an evidence-based review. Neuroimaging Clin N Am 13, 197-209.

[3] Jack CR, Jr., Petersen RC, Xu Y, O'Brien PC, Smith GE, Ivnik RJ, Boeve BF, Tangalos EG, Kokmen E (2000) Rates of hippocampal atrophy correlate with change in clinical status in aging and AD. Neurology 55, 484-489.

[4] Ghadimi M, Sapra A (2021) Magnetic Resonance Imaging Contraindications In StatPearls, Treasure Island (FL).

[5] Savalia NK, Agres PF, Chan MY, Feczko EJ, Kennedy KM, Wig GS (2017) Motionrelated artifacts in structural brain images revealed with independent estimates of inscanner head motion. Hum Brain Mapp 38, 472-492.

[6] Scharff DP, Mathews KJ, Jackson P, Hoffsuemmer J, Martin E, Edwards D (2010) More than Tuskegee: understanding mistrust about research participation. J Health Care Poor Underserved 21, 879-897.

[7] Shin J, Doraiswamy PM (2016) Underrepresentation of African-Americans in Alzheimer's Trials: A Call for Affirmative Action. Front Aging Neurosci 8, 123.

[8] Hoge C, Verma S, Lama DJ, Bergelson I, Haj-Hamed M, Maynor S, Gaitonde K, Sidana A (2020) Racial disparity in the utilization of multiparametric MRI-ultrasound fusion biopsy for the detection of prostate cancer. Prostate Cancer Prostatic Dis 23, 567-572. 
medRxiv preprint doi: https://doi.org/10.1101/2021.05.31.21258061; this version posted June 3, 2021. The copyright holder for this preprint (which was not certified by peer review) is the author/funder, who has granted medRxiv a license to display the preprint in perpetuity. It is made available under a CC-BY-NC-ND 4.0 International license .

[9] Kubicki A, Fautrelle L, Bourrelier J, Rouaud O, Mourey F (2016) The Early Indicators of Functional Decrease in Mild Cognitive Impairment. Front Aging Neurosci 8, 193.

[10] Rogojin A, Gorbet DJ, Hawkins KM, Sergio LE (2019) Cognitive-Motor Integration Performance Is Affected by Sex, APOE Status, and Family History of Dementia. $J$ Alzheimers Dis 71, 685-701.

[11] Toosizadeh N, Najafi B, Reiman EM, Mager RM, Veldhuizen JK, O'Connor K, Zamrini E, Mohler J (2016) Upper-Extremity Dual-Task Function: An Innovative Method to Assess Cognitive Impairment in Older Adults. Front Aging Neurosci 8, 167.

[12] Schaefer SY, Hooyman A, Duff K (2020) Using a Timed Motor Task to Predict OneYear Functional Decline in Amnestic Mild Cognitive Impairment. J Alzheimers Dis 77, 53-58.

[13] Hooyman A, Malek-Ahmadi M, Fauth EB, Schaefer SY (2021) Challenging the relationship of grip strength with cognitive status in older adults. Int J Geriatr Psychiatry 36, 433-442.

[14] Schaefer SY, Duff K (2017) Within-session and one-week practice effects on a motor task in amnestic mild cognitive impairment. J Clin Exp Neuropsychol 39, 473-484.

[15] Regan E, Fridriksson J, Schaefer SY, Rorden C, Bonilha L, Lingo VanGilder J, Stewart JC (2021) Neural correlates of within-session practice effects in mild motor impairment after stroke: a preliminary investigation. Exp Brain Res 239, 151-160.

[16] Lingo VanGilder J, Hengge CR, Duff K, Schaefer SY (2018) Visuospatial function predicts one-week motor skill retention in cognitively intact older adults. Neurosci Lett 664, 139-143. 
medRxiv preprint doi: https://doi.org/10.1101/2021.05.31.21258061; this version posted June 3, 2021. The copyright holder for this preprint (which was not certified by peer review) is the author/funder, who has granted medRxiv a license to display the preprint in perpetuity. It is made available under a CC-BY-NC-ND 4.0 International license .

[17] Duff K, Callister C, Dennett K, Tometich D (2012) Practice effects: a unique cognitive variable. Clin Neuropsychol 26, 1117-1127.

[18] Padovani A, Benussi A, Cantoni V, Dell'Era V, Cotelli MS, Caratozzolo S, Turrone R, Rozzini L, Alberici A, Altomare D, Depari A, Flammini A, Frisoni GB, Borroni B (2018) Diagnosis of Mild Cognitive Impairment Due to Alzheimer's Disease with Transcranial Magnetic Stimulation. J Alzheimers Dis 65, 221-230.

[19] ADNI2, Alzheimer's Disease Neuroimaging Initiative: ADNI2 Procedures Manual, https://adni.loni.usc.edu/wp-content/uploads/2008/07/adni2-procedures-manual.pdf, Accessed May 21.

[20] Folstein MF, Folstein SE, McHugh PR (1975) "Mini-mental state". A practical method for grading the cognitive state of patients for the clinician. J Psychiatr Res 12, 189-198.

[21] Morris JC (1993) The Clinical Dementia Rating (CDR): current version and scoring rules. Neurology 43, 2412-2414.

[22] Wechsler D (1987) Manual for the Weschler Memory Scale - Revised, The Psychological Corporation, San Antonio, Tx.

[23] Randolph C (1998) Repeatable Battery for the Assessment of Neuropsychological Status, The Psychological Corporation, San Antonio, TX.

[24] Hooyman A, Malek-Ahmadi M, Fauth EB, Schaefer SY (2020) Challenging the relationship of grip strength with cognitive status in older adults. Int J Geriatr Psychiatry.

[25] Schaefer SY, Dibble LE, Duff K (2015) Efficacy and Feasibility of Functional Upper Extremity Task-Specific Training for Older Adults With and Without Cognitive Impairment. Neurorehabil Neural Repair 29, 636-644. 
medRxiv preprint doi: https://doi.org/10.1101/2021.05.31.21258061; this version posted June 3, 2021. The copyright holder for this preprint (which was not certified by peer review) is the author/funder, who has granted medRxiv a license to display the preprint in perpetuity. It is made available under a CC-BY-NC-ND 4.0 International license .

[26] Schaefer SY, Duff K (2015) Rapid Responsiveness to Practice Predicts Longer-Term Retention of Upper Extremity Motor Skill in Non-Demented Older Adults. Front Aging Neurosci 7, 214.

[27] Delis DC, Kaplan E, Kramer JH, Ober BA (2000) California Verbal Learning TestSecond edition (CVLT-II) manual, Psychological Corporation, San Antonio, TX.

[28] Jones SN, Greer AJ, Cox DE (2011) Learning characteristics of the CERAD word list in an elderly VA sample. Appl Neuropsychol 18, 157-163.

[29] Fischl B, Dale AM (2000) Measuring the thickness of the human cerebral cortex from magnetic resonance images. Proc Natl Acad Sci U S A 97, 11050-11055.

[30] Fischl B, Salat DH, Busa E, Albert M, Dieterich M, Haselgrove C, van der Kouwe A, Killiany R, Kennedy D, Klaveness S, Montillo A, Makris N, Rosen B, Dale AM (2002) Whole brain segmentation: automated labeling of neuroanatomical structures in the human brain. Neuron 33, 341-355.

[31] Fischl B, Salat DH, van der Kouwe AJ, Makris N, Segonne F, Quinn BT, Dale AM (2004) Sequence-independent segmentation of magnetic resonance images. Neuroimage 23 Suppl 1, S69-84.

[32] Duff K, Anderson JS, Mallik AK, Suhrie KR, Atkinson TJ, Dalley BCA, Morimoto SS, Hoffman JM (2018) Short-term repeat cognitive testing and its relationship to hippocampal volumes in older adults. J Clin Neurosci 57, 121-125.

[33] Duff K, Horn KP, Foster NL, Hoffman JM (2015) Short-Term Practice Effects and Brain Hypometabolism: Preliminary Data from an FDG PET Study. Arch Clin Neuropsychol 30, 264-270. 
medRxiv preprint doi: https://doi.org/10.1101/2021.05.31.21258061; this version posted June 3, 2021. The copyright holder for this preprint

(which was not certified by peer review) is the author/funder, who has granted medRxiv a license to display the preprint in perpetuity.

It is made available under a CC-BY-NC-ND 4.0 International license.

[34] Duff K, Foster NL, Hoffman JM (2014) Practice effects and amyloid deposition:

preliminary data on a method for enriching samples in clinical trials. Alzheimer Dis Assoc

Disord 28, 247-252.

[35] Duff K, Beglinger LJ, Moser DJ, Schultz SK, Paulsen JS (2010) Practice effects and outcome of cognitive training: preliminary evidence from a memory training course. $\mathrm{Am}$ J Geriatr Psychiatry 18, 91.

[36] Duff K (2014) One-week practice effects in older adults: tools for assessing cognitive change. Clin Neuropsychol 28, 714-725.

[37] Wang P, Infurna FJ, Schaefer SY (2020) Predicting motor skill learning in older adults using visuospatial performance. Journal of Motor Learning and Development 8, 38-51.

[38] Lingo VanGilder J, Lohse KR, Duff K, Wang P, Schaefer SY (2021) Evidence for associations between Rey-Osterrieth Complex Figure test and motor skill learning in older adults. Acta Psychol (Amst) 214, 103261. 


\section{TABLES}

Table 1. Linear regression results for models with each motor task variable as a predictor of hippocampal volume, compared to the null model including RBANS Delayed Memory Index. Age, sex, years of education, and clinical status are controlled for in each model.

\begin{tabular}{lccccc}
\hline Model & $\boldsymbol{\beta}$ & $\mathbf{9 5 \%} \mathbf{C I}$ & $\mathbf{p}$-value & $\mathbf{R}^{\mathbf{2}}$ & AIC \\
\hline RBANS Delayed Memory Index & 0.009 & $(-0.005,0.02)$ & 0.21 & 0.32 & 128 \\
Motor task acquisition (SD) & -0.03 & $(-0.06,-0.009)$ & 0.04 & 0.36 & 125 \\
Mean motor task performance & -0.008 & $(-0.02,0.003)$ & 0.14 & 0.34 & 127 \\
Acquisition slope (Trial 6-Trial 1) & 0.02 & $(0.004,0.03)$ & 0.007 & 0.41 & 121 \\
\hline
\end{tabular}




\section{FIGURE}

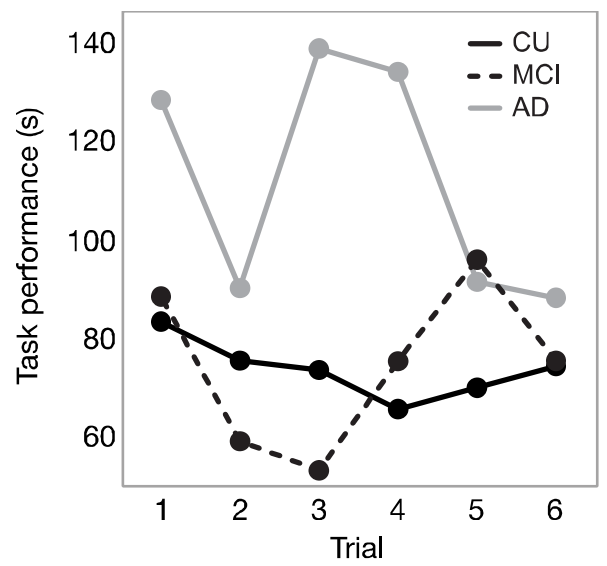

Figure 1. Task performance across six practice trials for a cognitively unimpaired (CU, solid black), aMCI (dashed black), and AD (gray) participant. (Note the difference in variability across the practice trials). Because participants within each clinical status group were not consistently variable across trials (i.e., the AD participants were not all slow on Trial 1, then faster on trial 2, etc.), the average data for each trial for each clinical status group is not shown graphically here; instead, individual participant data are provided to illustrate differences in intrasubject variability. 